\title{
The Evaluation of the Addition of Commercial Yeast with $\beta$-Glucan Content in Feed on the Immunity of Snakehead Fish Channa striata Infected by Aeromonas hydrophila Bacteria
}

\author{
Tiara Puspa Anjani ${ }^{1}$, Dinamella Wahjuningrum ${ }^{2 *}$, Sri Nuryati ${ }^{2}$ and Ikhsan Khasani ${ }^{3}$ \\ ${ }^{1}$ Aquaculture Science Study Program, Faculty of Fisheries and Marine Sciences, IPB, Indonesia \\ ${ }^{2}$ Department of Aquaculture, Faculty of Fisheries and Marine Sciences, IPB, Indonesia \\ ${ }^{3}$ Fish Breeding Research Institute, Sukamandi, Subang, Indonesia
}

*Correspondence :

dinamella@yahoo.com

Received : 2020-10-23

Accepted : 2021-03-22

Keywords :

Aeromonas hydrophila, Snakehead fish, Immunostimulant, Yeast

\begin{abstract}
Snakehead fish Channa striata is a high commercial freshwater fish commodity. It has the potential as a pharmaceutical ingredient. Intensive snakehead fish cultivation starts to experience a problem, namely Motile Aeromonas Septicemia (MAS) caused by Aeromonas hydrophila. The purpose of this study is to evaluate the effect of the addition of commercial yeast in feed to improve snakehead fish immunity. This study was designed with a completely randomized design (CRD) with 5 treatments with 3 replications (reared in the net) and 6 treatments with 3 replications (reared in the aquarium). The treatments were $\mathrm{K}$ (feed without yeast), F5 (feed with the addition of $5 \mathrm{~g} / \mathrm{kg}$ of cake yeast), R3 (feed with the addition of $3 \mathrm{~g} / \mathrm{kg}$ of tempeh yeast, R5(feed with the addition of $5 \mathrm{~g} / \mathrm{kg}$ of tempeh yeast), and R7 (feed with the addition of $7 \mathrm{~g} / \mathrm{kg}$ of tempeh yeast). The results show that the survival rate after 30 days is 88.89 $92.22 \%$. The best treatment after A. hydrophila infection was found in fish fed with $3 \mathrm{~g} / \mathrm{kg}$ of tempeh yeast with a survival rate of $56.67 \%$, total erythrocytes of $4.07 \times 10^{6} \mathrm{~mm}^{-3}$ cells, hemoglobin of $7.40 \mathrm{~g} \%$ of total leukocytes $4.97 \times 10^{4} \mathrm{~mm}^{-3}$ cells and phagocytic activity of 33.67. In conclusion, the addition of tempeh yeast at a dose of $3 \mathrm{~g} / \mathrm{kg}$ could be used as an alternative to prevent the effect of $A$. hydrophila pathogen infection in snakehead fish.
\end{abstract}

\section{INTRODUCTION}

Snakehead fish Channa striata is a freshwater fish commodity that has economic value due to its high demand. This is because snakehead fish contains albumin which is beneficial for human health (Listyanto and Andriyanto, 2009; Chasanah et al., 2015). Albumin is a protein that is useful in the healing of the postoperative wound (Mustafa et al., 2012). The high demand for snakehead fish encourages some efforts to increase the production of the snakehead fish cultivation sector every year. FAO statistical data (2018) reported that snakehead fish production increased from 2010 to 2016, accounting for 377 tons, 481 tons, 511 tons, 518 tons. Nevertheless, several obstacles in snakehead fish farming activities begin to occur, one of which is caused by the factor of diseases (Olga, 2012). 
One of the common diseases that often infect snakehead fish is Motile Aeromonas septicemia (MAS), which is caused by the Aeromonas hydrophila bacteria (KKP BPBAT, 2014). MAS disease is characterized by bleeding in the gills, kidney damage, and dropsy. This disease can cause death in snakehead fish from $23.30 \%$ to $100 \%$ (Olga, 2012). A series of efforts to overcome MAS have been carried out immunostimulants, one of which is the provision of vitamin C (Dwinanti et al., 2019). However, vitamin $\mathrm{C}$ has a high price, so it can increase production costs.

One of the immunostimulants that can increase immunity is yeast. Research on the use of cake yeast as an immunostimulant in fish has been widely reported, including the addition of $5 \mathrm{~g} / \mathrm{kg}$ of cake yeast to the feed which can increase the survival rate after Aeromonas hydrophila injection and can reduce the number of bacteria (Abdel-Tawwab et al., 2008; Manoppo et al., 2015). The addition of $5 \mathrm{~g} / \mathrm{kg}$ of cake yeast to the feed of rohu fish can increase the immunity (Pal et al., 2007), and the addition of yeast as much as $1.5,10 \mathrm{~g} / \mathrm{kg}$ to the feed of snapper can increase the immune response (Ortuño et al., 2002). The addition of cake yeast to the feed can increase the survival rate of the fish against MAS disease infection, increase hemoglobin, and increase phagocytic activity. Research on the use of $5 \mathrm{~g} / \mathrm{kg}$ of yeast to feed as an immunostimulant in fish has been widely conducted. However, information regarding the use of tempeh yeast, which is cheaper, easy to obtain, and easy to apply as an immunostimulant in fish is still very limited.

Tempeh yeast is a Rhizopus oligosporus culture that contains $8 \% \beta$ glucan (Purwijantiningsih et al., 2005). The $\beta$-glucan content which enters the body can induce phagocytic activity and lysozyme activity (Stier et al., 2014). This content will activate the lysozyme gene so that the innate body defenses will be stronger against bacterial diseases. The use of tempeh yeast in increasing fish immunity has never been done before. Therefore, there is a need for research on the addition of tempeh yeast to the feed in snakehead fish. This study aims to evaluate and analyze the effectiveness of commercial yeast as an immunostimulant for snakehead fish (C. striata).

\section{METHODOLOGY}

\section{Place and Time}

This research was conducted from January to August 2019 at the Sukamandi Fish Breeding Research Institute (BRPI), Subang West Java, Fish Health Laboratory, Department of Aquaculture, FPIK, IPB, and several analyzes were carried out at the Station for Investigation of Fish Health and Environment (LP2IL), Serang, Banten.

\section{Research Materials}

The yeasts used in this research were cake yeast and commercial tempeh yeast. The fish used were snakehead fish measuring $7.37 \pm 0.12 \mathrm{~cm}$, coming from BRPI Sukamandi, Subang. The bacterial isolate used was A. hydrophila coming from the collection of the Sukamandi BRPI Microbiology Laboratory. The bacteria were cultured on Rhimler Shotts (RS) medium and were incubated for 24 hours at a temperature of $37^{\circ} \mathrm{C}$. The bacteria were then tested for their virulence and were identified biochemically using KIT API $20 \mathrm{NE}$ to determine the type of isolate.

\section{Research Design}

The design used in this study was a completely randomized design (CRD) with five treatments (in a net) and six treatments (in an aquarium) with three replications. Net treatment was done by giving feed without yeast (K), feed with cake yeast of $5 \mathrm{~g} / \mathrm{kg}$ (F5), feed with tempeh yeast of $3 \mathrm{~g} / \mathrm{kg}$ (R3), feed with yeast tempeh of $5 \mathrm{~g} / \mathrm{kg}$ (R5), and feed with yeast tempeh of $7 \mathrm{~g} / \mathrm{kg}$ (R7). Meanwhile, the aquarium treatment included feed without the addition of yeast and fish injected with Aeromonas hydrophila $(\mathrm{K}+)$, feed without the 
addition of yeast and fish injected with phosphate buffer saline (PBS) (K-), feed with cake yeast of $5 \mathrm{~g} / \mathrm{kg}$ and fish injected with $A$. hydrophila (F5), feed with tempeh yeast of $3 \mathrm{~g} / \mathrm{kg}$ and fish injected with $A$. hydrophila (R3), feed with tempeh yeast of $5 \mathrm{~g} / \mathrm{kg}$ and fish injected with $A$. hydrophila (R5), and feed with tempeh yeast of 7 $\mathrm{g} / \mathrm{kg}$ of tempeh yeast and fish injected with A. hydrophila (R7).

\section{Work Procedures}

Feed Manufacturing and Testing of $\beta$-glucans
The feed used was commercial feed with a protein content of $40 \%$. The feed was floured, and yeast was added according to the treatment, $2 \%$ of eggs, and $100 \mathrm{~mL}$ of water. The feed was then added with flour (repeletting) and heated in the oven $\left(50{ }^{\circ} \mathrm{C}\right)$ for six hours. Afterward, the feed was cooled and stored at room temperature. Moreover, $90 \mathrm{mg}$ of feed samples were taken for the analysis of $\beta$-glucan content (Table 1). Samples were analyzed in LP2IL Serang using the Megazyme K-YBGL Kit (USA) and read using a UV-Visible GBC 911 machine (USA).

Table 1. $\quad \beta$-glucan content in pure yeast and yeast mixture in feed.

\begin{tabular}{ll}
\hline Sample & Percentage (\%) \\
\hline Cake yeast & 36.04 \\
Tempeh yeast & 41.89 \\
Feed with yeast tempeh of $3 \mathrm{~g} \mathrm{Kg}-1$ (R3) & 16.10 \\
Feed with yeast tempeh of 7 g Kg-1 (R7) & 18.49 \\
Feed with cake yeast of 5 g Kg-1 (F5) & 16.56 \\
\hline
\end{tabular}

\section{Fish Farming}

The seeds of snakehead fish were reared in a net measuring $2 \times 2 \times 1 \mathrm{~m}$ for 30 days with a density of 30 fish per net. Feed was given twice a day ad satiation. During maintenance, the quality of the water was made to be suitable for the life of snakehead fish, by adding new water of around $10 \%$ of the pond volume per day and giving aeration.

\section{Challenge Test on Fish}

The challenge test was carried out on snakehead fish seeds that had been treated with different $\beta$-glucan doses for 30 days. The fish were put into an aquarium measuring $60 \times 60 \times 40 \mathrm{~cm}$ and then acclimatized for seven days. The challenge test was carried out by injecting $0.1 \mathrm{~mL}$ of the A. hydrophila bacteria culture (106 cfu/mL) intramuscularly. Afterward, the snakehead fish mortality was observed every day for 18 days, and the cause of death of the fish was identified. Moreover, bacteria isolated from dead fish were identified biochemically using KIT API 20 NE.

\section{Research Parameters}

Parameters observed included fish growth, survival rate, blood picture, lysozyme activity and the G-type lysozyme gene expression. Specifically, blood picture parameters included total erythrocytes, total leukocytes (Blaxhall and Daisley, 1973), and hemoglobin (Wedemeyer and Yasatuke, 1977). Phagocytic activity (Anderson and Siwicki, 1995) was observed at the pre-challenge test (H-30 and $\mathrm{H}-1)$ and post-challenge test $(\mathrm{H}+2, \mathrm{H}+4$, and $\mathrm{H}+6)$. Lysozyme activity (Hanif et al., 2004) and G-type lysozyme gene expression (Kumaresan et al., 2015) were observed in the prechallenge test ( $\mathrm{H}-1)$ and post-challenge test $(H+2)$.

\section{Data Analysis}

The research data were tabulated using Ms. program. Office Excel 2010. Data analysis was performed using oneway ANOVA through the SPSS program version 20. The results which were significantly different were further tested with the Duncan test at a 95\% confidence interval. 


\section{RESULTS AND DISCUSSION Growth Performance}

In the cultivation of snakehead fish for 30 days in a net, feeding enriched with yeast has no significant effect $(P>0.05)$ on the survival rate (TKH), total feed consumption (JKP), and feed conversion ratio (FCR) (Table 2) for 30 days of cultivation. This is because, during fish rearing, the optimal conditions for snakehead fish life were maintained, without any treatment that triggered stress on the fish. The results obtained are in accordance with the results of research by Adloo et al. (2015), which states that giving yeast to feed does not have a significant effect on either TKH, JKP, or
FCR on catfish that are kept in normal conditions, and there is no trigger of stress on fish. Meanwhile, Misra et al. (2006) reported that the addition of feed with yeast containing glucans can increase immunity, growth, and TKH of Labeo rohita fish infected with $A$. hydrophila bacteria. The differences in the results obtained in these previous studies are due to differences in the treatments given. According to Pilarski et al. (2017) and Whittington et al. (2005), the effect of the addition of immunostimulants on TKH, JKP, and RKP is influenced by environmental conditions, types of feed, length of fish maintenance, and types of fish cultivated.

Table 2. Total feed consumption (JKP), specific growth rate (LPS), feed conversion ratio (FCR), and survival rate (TKH) of snakehead fish during 30 days of cultivation.

\begin{tabular}{|c|c|c|c|c|c|}
\hline \multirow[t]{2}{*}{ Parameter } & \multicolumn{5}{|l|}{ Treatment } \\
\hline & $\mathrm{K}$ & F5 & R3 & R5 & R7 \\
\hline JKP (g) & $128.68 \pm 1.33^{\mathrm{a}}$ & $132.81 \pm 2.01^{\mathrm{a}}$ & $131.92 \pm 1.27^{\mathrm{a}}$ & $140.12 \pm 1.40^{\mathrm{b}}$ & $132.63 \pm 1.42^{\mathrm{a}}$ \\
\hline LPS (g/day) & $4.78 \pm 0.08^{\mathrm{abc}}$ & $4.57 \pm 0.17^{\mathrm{ab}}$ & $5.08 \pm 0.12^{\mathrm{c}}$ & $4.51 \pm 0.20^{\mathrm{bc}}$ & $4.96 \pm 0.38^{\mathrm{a}}$ \\
\hline FCR & $0.70 \pm 0.06^{\mathrm{a}}$ & $0.86 \pm$ & $0.74=$ & $0.95 \pm$ & $0.78 \pm 0.20^{\mathrm{a}}$ \\
\hline TKH (\%) & $88.33 \pm 1.58^{\mathrm{a}}$ & $92.22 \pm 1.18^{\mathrm{a}}$ & $88.89 \pm 1.70^{\mathrm{a}}$ & $91.11 \pm 1.62^{\mathrm{a}}$ & $90.00 \pm 1.61^{\mathrm{a}}$ \\
\hline
\end{tabular}

"different notations on the lines indicate significant differences at the $5 \%$ test level (Duncan's multiple interval test). Control (K), cake yeast of $5 \mathrm{~g} / \mathrm{Kg}$ (F5), tempeh yeast of $3 \mathrm{~g} / \mathrm{Kg}$ (R3), tempeh yeast of 5 $\mathrm{g} / \mathrm{Kg}$ (R5), and tempeh yeast of $7 \mathrm{~g} / \mathrm{Kg}$ (R7).

\section{Post-Challenge Test Survival Rates}

The effect of giving yeast which contains $\beta$-glucan on the survival rate of the fish is very significant in the postchallenge test with pathogenic bacteria $A$. hydrophila. The percentage of TKH of post-challenge test with $A$. hydrophila shows a difference $(\mathrm{P}<0.05)$ between $\mathrm{K}+$ and K-, F5, R3, while other treatments were not significantly different $(\mathrm{P}>0.05)$ (Figure 1). TKH in the R3 treatment $(56.67 \%)$ is higher than that in $\mathrm{K}+$ (13.33\%) (Figure 1). These results indicate that the administration of $\beta$ glucan in the appropriate amount is effective in increasing the immunity of snakehead fish. These results are consistent with the results of research by Kumari and Sahoo (2006) and Domenico et al. (2017) which states that giving yeast containing $\beta$-glucan increases the immunity of fish after pathogenic bacterial infection, by activating macrophages so that they can fight these bacterial infections. The mechanism of $\beta$-glucan in increasing fish immunity is $\beta$-glucan which binds to the toll-like receptor (TLR) and Complement receptor 3 (CR 3) will activate macrophages, further increasing the activity of hydrolytic enzymes and signaling processes that lead to the activation of phagocytosis and secretion of cytokines (Vetvicka and Vetvickova, 2016; Kumar et al., 2013). However, giving $\beta$ glucan in excessive amounts will inhibit the fish's immune mechanism, which can lead to death. The $\beta$-glucan levels in the body will stimulate the phagocytic cells of fish that exceed their ability, thereby reducing the activity of these phagocytic cells in killing bacteria (Vechklang et al., 2011).

These results indicate that in the application of immunostimulants, the dose 
and length of time of administration need to be given attention because prolonged administration with high doses can suppress the immune system (immunosuppression) of fish (Sakai,
1999). Sajeevan et al. (2009) further stated that the dose and duration of immunostimulant administration are very important in fish health management.

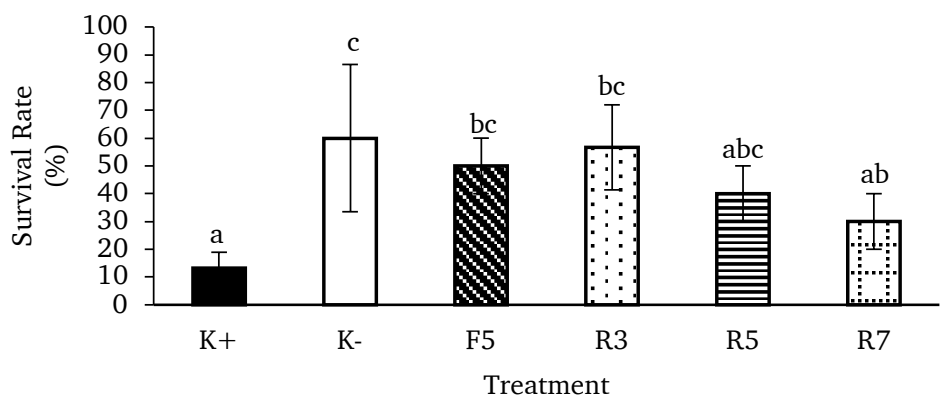

Figure 1. The survival rate of snakehead fish after A. hydrophila bacteria injection at the end of treatment. Different letters in each treatment show significantly different results ( $\mathrm{P}<0.05)$. Positive control $(\mathrm{K}+)$, negative control (K-), cake yeast of 5 $\mathrm{g} / \mathrm{Kg}$ (F5), tempeh yeast of $3 \mathrm{~g} / \mathrm{Kg}$ (R3), tempeh yeast of $5 \mathrm{~g} / \mathrm{Kg}$ (R5), and tempeh yeast of $7 \mathrm{~g} / \mathrm{Kg}$ (R7).

\section{Blood Picture}

Immunostimulants affect the parameters of the blood picture, and several blood image parameters show fluctuation values. Total erythrocytes on the second day of post-challenge test $(\mathrm{H}$ + 2) decreases and is significantly different $(\mathrm{P}<0.05)$ with the $\mathrm{K}+$ treatment. Meanwhile, total erythrocytes in treatment R3 have a higher value compared to those in treatment $\mathrm{K}+$ (Table 3 ). Snakehead fish fed with yeast content have a higher survival rate after $A$. hydrophila infection because $\beta$-glucan stimulates the immune system to work faster. Erythrocytes in the post-challenge test of snakehead fish tend to decrease due to pathogenic bacteria which lysate erythrocytes, so after infection the number decreases. The normal number of erythrocytes in snakehead fish is 2.17-2.47 x 106 cells/mm (Wahyu, 2015), while the number of erythrocytes in snakehead fish at $\mathrm{K}+$ is below $2.0 \times 106$ cells $/ \mathrm{mm}$. The total number of erythrocytes of snakehead fish decreases in the post-challenge test with A. hydrophila bacteria. The decrease in the total number of erythrocytes is caused by the infection of $A$. hydrophila, which causes hemolytic activity. Ray et al. (2016) further state that A. hydrophila produces exotoxin in the form of hemolysin, which is an enzyme that can lysate erythrocytes and free hemoglobin so that the erythrocytes of the infected fish decrease. Moreover, the total number of erythrocytes in $\mathrm{K}+$ treatment is lower than that in $\mathrm{K}$ - and other treatments. This shows that the immune system in snakehead fish that is given yeast works faster so that the impact of bacterial infection on erythrocyte lysis is lower.

Hemoglobin is the red pigment that carries oxygen in erythrocytes. Hemoglobin in snakehead fish infected with pathogens decreases, presumably because the amount of oxygen in the fish's body reduces due to the decrease in the number of erythrocytes. However, hemoglobin on the fourth day of the postchallenge test $(\mathrm{H}+4)$ has an increase and is significantly different $(\mathrm{P}<0.05)$. As stated by Ray et al. (2016), A. hydrophila infection causes erythrocytes to experience lysis and hemoglobin levels to fall. The relationship between the total number of erythrocytes and hemoglobin level is stated by Harikrishnan et al. 
(2003), who states that pathogenic infections cause erythrocytes to be damaged so that oxygen entering cells reduces.

Table 3. Total number of erythrocytes, hemoglobin (hb), total leukocytes (leu) and phagocytic activity (AF), and lysozyme activity (AL) of snakeheadfish during prechallenge and posy-challenge tests with Aeromonas hydrophila bacteria.

\begin{tabular}{|c|c|c|c|c|c|c|c|}
\hline \multirow{2}{*}{ Treatment } & \multicolumn{7}{|c|}{ Treatment } \\
\hline & & $\mathrm{K}+$ & K- & F5 & R3 & R5 & R7 \\
\hline \multirow{5}{*}{$\begin{array}{c}\text { Erit } \\
\left(\mathrm{x} 10^{6} \text { cell }\right. \\
\left.\mathrm{mm}^{-3}\right)\end{array}$} & $\mathrm{H}-30$ & $1.11 \pm 0.83$ & $1.11 \pm 0.83$ & $1.11 \pm 0.83$ & $1.11 \pm 0.83$ & $1.11 \pm 0.83$ & $1.11 \pm 0.83$ \\
\hline & H-1 & $1.65 \pm 0.60^{\mathrm{a}}$ & $1.65 \pm 0.60^{\mathrm{a}}$ & $3.21 \pm 0.70^{\mathrm{d}}$ & $2.10 \pm 0.94^{\mathrm{c}}$ & $1.95 \pm 0.87^{\mathrm{b}}$ & $3.23 \pm 1.28^{\mathrm{d}}$ \\
\hline & $\mathrm{H}+2$ & $1.21 \pm 0.46^{\mathrm{a}}$ & $1.54 \pm 1.17^{\mathrm{d}}$ & $1.29 \pm 0.53^{b}$ & $1.77 \pm 0.23^{\mathrm{e}}$ & $1.36 \pm 0.12^{c}$ & $1.27 \pm 1.01^{\mathrm{ab}}$ \\
\hline & $\mathrm{H}+4$ & $2.96 \pm 0.53^{c}$ & $2.35 \pm 0.12^{\mathrm{a}}$ & $3.63 \pm 1.11^{\mathrm{e}}$ & $4.07 \pm 0.76^{f}$ & $3.17 \pm 0.76^{d}$ & $2.56 \pm 0.31^{\mathrm{b}}$ \\
\hline & $\mathrm{H}+6$ & $2.53 \pm 0.64^{d}$ & $2.54 \pm 0.12^{\mathrm{d}}$ & $2.27 \pm 0.31^{\mathrm{c}}$ & $2.85 \pm 0.53^{\mathrm{e}}$ & $2.15 \pm 1.25^{\mathrm{b}}$ & $2.02 \pm 0.95^{\mathrm{a}}$ \\
\hline \multirow{5}{*}{$\begin{array}{c}\mathrm{Hb} \\
(\mathrm{g} \%)\end{array}$} & $\mathrm{H}-30$ & $6.07 \pm 0.12$ & $6.07 \pm 0.12$ & $6.07 \pm 0.12$ & $6.07 \pm 0.12$ & $6.07 \pm 0.12$ & $6.07 \pm 0.12$ \\
\hline & $\mathrm{H}-1$ & $6.40 \pm 0.40^{\mathrm{a}}$ & $6.40 \pm 0.40^{\mathrm{a}}$ & $8.13 \pm 0.31^{b}$ & $7.87 \pm 0.42^{\mathrm{b}}$ & $7.80 \pm 0.20^{\mathrm{b}}$ & $7.47 \pm 0.31^{\mathrm{b}}$ \\
\hline & $\mathrm{H}+2$ & $4.73 \pm 0.31^{\mathrm{a}}$ & $6.07 \pm 0.12^{\mathrm{d}}$ & $5.13 \pm 0.23^{\mathrm{ab}}$ & $5.80 \pm 0.20^{\mathrm{cd}}$ & $4.87 \pm 0.12^{\mathrm{a}}$ & $5.40 \pm 0.40^{\mathrm{bc}}$ \\
\hline & $\mathrm{H}+4$ & $5.47 \pm 0.60^{\mathrm{a}}$ & $7.20 \pm 0.20^{\mathrm{b}}$ & $5.60 \pm 0.20^{\mathrm{a}}$ & $7.00 \pm 0.92^{\mathrm{b}}$ & $5.40 \pm 0.40^{\mathrm{a}}$ & $7.27 \pm 0.46^{\mathrm{b}}$ \\
\hline & $\mathrm{H}+6$ & $5.53 \pm 0.50^{\mathrm{b}}$ & $5.47 \pm 0.50^{\mathrm{b}}$ & $4.07 \pm 0.12^{\mathrm{a}}$ & $7.40 \pm 0.40^{c}$ & $6.60 \pm 0.53^{c}$ & $7.40 \pm 0.40^{c}$ \\
\hline \multirow{5}{*}{$\begin{array}{c}\text { Leu } \\
\left(\mathrm{x} 10^{4} \text { cell }\right. \\
\left.\mathrm{mm}^{-3}\right)\end{array}$} & H-30 & $1.97 \pm 0.70$ & $1.97 \pm 0.70$ & $1.97 \pm 0.70$ & $1.97 \pm 0.70$ & $1.97 \pm 0.70$ & $1.97 \pm 0.70$ \\
\hline & $\mathrm{H}-1$ & $2.40 \pm 1.00^{\mathrm{b}}$ & $2.40 \pm 0.20^{\mathrm{b}}$ & $2.27 \pm 0.20^{\mathrm{b}}$ & $1.60 \pm 0.60^{\mathrm{a}}$ & $1.67 \pm 0.50^{\mathrm{a}}$ & $1.90 \pm 0.52^{\mathrm{a}}$ \\
\hline & $\mathrm{H}+2$ & $2.37 \pm 0.31^{\mathrm{a}}$ & $2.50 \pm 0.35^{\mathrm{ab}}$ & $3.43 \pm 0.83^{b c}$ & $3.67 \pm 0.83^{b}$ & $3.03 \pm 0.8^{\mathrm{abc}}$ & $4.03 \pm 0.61^{b}$ \\
\hline & $\mathrm{H}+4$ & $2.57 \pm 0.6 \mathrm{a}^{\mathrm{b}}$ & $1.77 \pm 0.70^{\mathrm{a}}$ & $2.10 \pm 0.20^{\mathrm{a}}$ & $4.97 \pm 0.46^{c}$ & $3.33 \pm 0.92^{\mathrm{b}}$ & $1.90 \pm 0.87^{\mathrm{a}}$ \\
\hline & $\mathrm{H}+6$ & $2.47 \pm 0.90^{\mathrm{b}}$ & $1.17 \pm 0.30^{\mathrm{a}}$ & $2.97 \pm 0.46^{\mathrm{bc}}$ & $1.57 \pm 0.64^{\mathrm{a}}$ & $2.40 \pm 0.20^{\mathrm{b}}$ & $3.47 \pm 0.57^{c}$ \\
\hline \multirow{5}{*}{$\begin{array}{l}\mathrm{AF} \\
(\%)\end{array}$} & $\mathrm{H}-30$ & $14.67 \pm 5.67$ & $14.67 \pm 5.67$ & $14.67 \pm 5.67$ & $14.67 \pm 5.67$ & $14.67 \pm 5.67$ & $14.67 \pm 5.67$ \\
\hline & $\mathrm{H}-1$ & $19.33 \pm 2.00^{\mathrm{b}}$ & $19.33 \pm 2.08^{\mathrm{b}}$ & $14.67 \pm 4.04^{\mathrm{ab}}$ & $9.67 \pm 1.57^{\mathrm{ab}}$ & $15.00 \pm 4.35^{\mathrm{ab}}$ & $13.33 \pm 3.51^{\mathrm{ab}}$ \\
\hline & $\mathrm{H}+2$ & $27.33 \pm 6.10^{\mathrm{bc}}$ & $17.33 \pm 2.50^{\mathrm{a}}$ & $35.00 \pm 5.29^{c}$ & $21.33 \pm .50^{\mathrm{ab}}$ & $32.67 \pm 3.20^{c}$ & $36.00 \pm 6.20^{c}$ \\
\hline & $\mathrm{H}+4$ & $21.00 \pm 3.00^{\mathrm{bc}}$ & $12.33 \pm 2.50^{\mathrm{a}}$ & $21.67 \pm 3.00^{\mathrm{bc}}$ & $33.67 \pm 3.00^{d}$ & $27.67 \pm 4.00^{\mathrm{cd}}$ & $17.33 \pm 3.00^{\mathrm{ab}}$ \\
\hline & $\mathrm{H}+6$ & $20.60 \pm 3.20^{\mathrm{b}}$ & $7.67 \pm 2.51^{\mathrm{a}}$ & $24.00 \pm 3.08^{b}$ & $17.70 \pm 2.51^{\mathrm{b}}$ & $20.00 \pm 1.00^{b}$ & $16.00 \pm 2.57^{\mathrm{ab}}$ \\
\hline \multirow{2}{*}{$\begin{array}{c}\mathrm{AL}(\mathrm{IU} / \mathrm{mL} / \\
\text { minute) }\end{array}$} & $\mathrm{H}-1$ & $25.33 \pm 4.00^{b c}$ & $25.33 \pm 4.00^{b c}$ & $34.17 \pm 0.17^{\mathrm{cd}}$ & $17.00 \pm 1.00^{\mathrm{b}}$ & $12.67 \pm 2.33^{\mathrm{a}}$ & $38.00 \pm 1.67^{c}$ \\
\hline & $\mathrm{H}+2$ & $1.67 \pm 1.00^{\mathrm{a}}$ & $8.00 \pm 3.00^{\mathrm{a}}$ & $36.67 \pm 3.33^{c}$ & $20.83 \pm 6.50^{\mathrm{ab}}$ & $28.83 \pm 3.17^{\text {bc }}$ & $35.00 \pm 1.67^{\mathrm{cd}}$ \\
\hline
\end{tabular}

The high survival rate of snakehead fish is closely related to the effectiveness of the fish immune system, which is indicated by the number of leukocytes, phagocytic activity, and lysozyme activity. The total number of leukocytes on the second day of the post-challenge test $(\mathrm{H}+$ $2)$ is not significantly different $(P>0.05)$ between treatments. The highest total number of leukocytes at $\mathrm{H}+2$ is observed in treatment R3 (Table 3). The total number of leukocytes in the body reflects the health status of the fish, especially when there is a pathogenic infection. Specifically, the total number of leukocytes of snakehead fish in the postchallenge test increases, as a result of infection with A. hydrophila bacteria. The pathogenic infection causes inflammation, which is a form of fish immune response to the infection, resulting in an increase in body immunity through the production of leukocytes which are responsible for phagocytosis of bacteria and synthesis of antibodies (Lagler et al., 1977; Moyle and Cech, 2004). The total number of leukocytes in the post-challenge test increases to more than $3.0 \times 10^{5} \mathrm{~mm}^{-3}$ cells, almost double the total number of leukocytes of snakehead fish under normal conditions, which is around $1.86 \times 10^{5}$ $\mathrm{mm}^{-3}$ cells (Wahyu, 2015).

In line with the total number of leukocytes, the phagocytic activity of snakehead fish also increases on the fourth day of the post-challenge test $(\mathrm{H}+4)$. Phagocytic activity is the ability of the nonspecific immune system to phagocytose foreign bodies. In the R3 treatment, phagocytic activity is observed on the fourth day of the post-challenge test $(\mathrm{H}+$ 4), with a higher value compared to that 
in other treatments (Table 3). Phagocytic activity in snakehead fish increases due to the infection with A. hydrophila bacteria. Cells that work to phagocytose foreign bodies are macrophages and monocytes. The mechanism of macrophages as a form of phagocytes in killing foreign antigens is oxidative. This mechanism is also employed by $\beta$-glucans, which kill bacteria by oxidative means. In this mechanism, phagocytic cells produce excess reactive oxygen (ROS) so that it can kill germs (Amin, 2016).

Lysozymes are widely distributed in fish bodies and are part of the non-specific immune system (Uribe et al., 2011), which are bactericidal enzymes, by breaking the $\beta-1.4-$ glycoside bond between acid-Nacetyl-glucosamine and acid-N-acetylmuramate in peptidoglycan so that it can damage bacteria (Kusumaningrum et al., 2018). Lysozyme activity in the postchallenge test of snakehead fish fed with the addition of yeast also increases in a higher value than that in the $\mathrm{K}+$ and $\mathrm{K}$ treatments (Table 3). The highest lysozyme activity in the pre-challenge test in the R7 treatment, while in the postchallenge test it is observed in the F5 treatment. In short, lysozyme activity in snakehead fish fed with the addition of yeast increases, both in the pre-challenge and post-challenge tests. This is assumed to occur because the $\beta$-glucan content activates phagocytic cells. This is in accordance with the research results of Paulsen et al. (2003), stating that the addition of $\beta$-glucan in salmon will increase neutrophils and macrophages which are the main sources of lysozyme so that their activity will increase.

\section{G-Type Lysozyme Expression}

The expression of G-type lysozyme genes in almost all treatments increases from pre-challenge test to post-challenge test. The G-type lysozyme gene in the R3 treatment is expressed 1.5 times compared to that in $\mathrm{K}$, while in the R5 treatment it is expressed 4 times more than that in $\mathrm{K}$ (Figure 2). In short, the expression of the G-type lysozyme gene and serum lysozyme in snakehead fish generally increases in both pre-test and post-challenge tests. This is because $\beta$-glucan increases the nonspecific immune response of fish, one of which is by synthesizing lysozyme. As stated by Sirimanapong et al. (2015), $\beta$ glucan will stimulate the expression of immune genes in most of the important organs of fish.

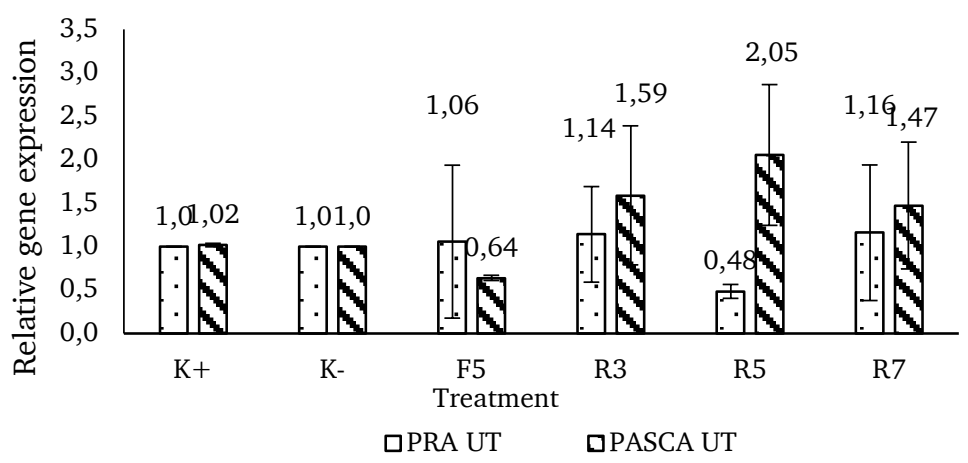

Figure 2. Expression of the lysozyme genes of snakeheadfish in pre-challenge test (H-1) and post-challenge test $(\mathrm{H}+2)$, Control (K), cake yeast $5 \mathrm{~g} \mathrm{Kg}-1$ (F5), tempeh yeast of $3 \mathrm{~g} \mathrm{Kg}-1$ (R3), tempeh yeast of $5 \mathrm{~g} \mathrm{Kg}-1$ (R5), and tempeh yeast of $7 \mathrm{~g}$ Kg-1 (R7).

\section{CONCLUSION}

The addition of $3 \mathrm{~g} \mathrm{Kg}^{-1}$ of tempeh yeast to the feed has a positive effect on snakehead fish immunity, which is marked by an increase in blood picture (leukocytes, erythrocytes, and phagocytic activity) and the survival rate of 
snakeheadfish in the post-challenge test with Aeromonas hydrophila bacteria.

\section{ACKNOWLEDGMENT}

The authors would like to thank all people and parties who have helped the smooth accomplishment of this research.

\section{REFERENCES}

Abdel-Tawwab, M., Abdel-Rahman, A.M. and Ismael, N.E., 2008. Evaluation of commercial live bakers' yeast, Saccharomyces cerevisiae as a growth and immunity promoter for Fry Nile tilapia, Oreochromis niloticus (L.) challenged in situ with Aeromonas hydrophila. Aquaculture, 280(1-4), pp.185-189. https://doi.o rg/10.1016/j.aquaculture.2008.03. 055

Adloo M.N., Soltanian, S., Hafeziyeh, M. and Ghadimi, N., 2015. Effects of long term dietary administration of $\beta$-Glucan on the growth, survival and some blood parameters of striped catfish, Pangasianodon hypophthalmus (Siluriformes: Pangasiidae). Iranian Journal of Ichthiology, 2(3), pp.194-200. http:/ /dx.doi.org/10.22034/iji.v2i3.75

Amin, M., 2016. Evaluasi ragi bir (Saccharomyces cerevisiae) sebagai sumber protein dan imunostimulan pada benih dan induk ikan nila (Oreochromis niloticus) [Disertasi]. Bogor (ID): IPB.

Anderson, D.P. and Siwicki, A.K., 1995. Basic hematology and serology for fish health programs. Fish Health Section, Asian Fisheries Society, pp.185-202.

Blaxhall, P.C. and Daisley, K.W., 1973. Routine haematological methods for use with fish blood. Journal of fish biology, 5(6), pp.771-781. https://d oi.org/10.1111/j.1095-8649.1973.t

Chasanah, E., Nurilmala, M., Purnamasari, A.R. and Fithriani, D., 2015. Komposisi kimia, kadar albumin dan bioaktivitas ekstrak protein ikan gabus (Channa striata) alam dan hasil budidaya. Jurnal Pascapanen dan Bioteknologi Kelautan dan Perikanan, 10(2), pp.123-132. http://dx.doi.org/10.15578/jpbkp. v10i2.364

Domenico, J.D., Canova, R., Soveral, L.D.F., Nied, C.O., Costa, M.M., Frandoloso, R. and Kreutz, L.C., 2017. Immunomodulatory effects of dietary $\beta$-glucan in silver catfish (Rhamdia quelen). Pesquisa Veterinária Brasileira, 37(1), pp.7378. https://pesquisa.bvsalud.org/po $\mathrm{rtal} / \mathrm{resource} / \mathrm{pt} / \mathrm{biblio}-846421$

Dwinanti, S.H., Afriani, S. and Sasanti, A.D., 2019. Pemanfaatan vitamin C untuk meningkatkan performa imunitas benis Ikan Gabus (Channa striata). J. Akuakultur Rawa Indonesia, 7(1), pp.67-76. https://c ore.ac.uk/download/pdf/26782272 3.pdf

FAO Food and Agriculture Organization, 2018. The State of World Fisheries and Aquaculture Meeting The Sustainable Development Goals. Rome:Food and Agriculture Organization.

Hanif, A., Bakopoulos, V. and Dimitriadis, G.J., 2004. Maternal transfer of humoral specific and non-specific immune parameters to sea bream (Sparus aurata) larvae. Fish \& shellfish immunology, 17(5), pp.411435. https://doi.org/10.1016/j.fsi.2

Harikrishnan, R., Rani, M.N. and Balasundaram, C., 2003. Hematological and biochemical parameters in common carp, Cyprinus carpio, following herbal treatment for Aeromonas hydrophila infection. Aquaculture, 221(1-4), pp.41-50. https://doi.org /10.1016/S0044-8486(03)00023-1

KKP BPBAT Kementrian Kelautan dan Perikanan Balai Perikanan Budidaya Air Tawar Mandiangin, 2014. Naskah Akademik Ikan Gabus Haruan (Channa striata Bloch 1793) Hasil Domestikasi (ID). Mandiangin : Direktorat Jendral Perikanan Budidaya. p.67. 
Kumar, P., Jain, K.K., Munilkumar, S. and Chalal, R.S., 2013. Beta Glucan : a valuable nutraceutical for promoting health in aquaculture (short review). African Journal of Basic \& Applied Sciences, 5(5), pp.220-227. 10.5829/idosi.ajbas.20 13.5.5.7625

Kumaresan, V., Bhatt, P., Ganesh, M.R., Harikrishnan, R., Arasu, M., AlDhabi, N.A., Pasupuleti, M., Marimuthu, K. and Arockiaraj, J., 2015. A novel antimicrobial peptide derived from fish goose type lysozyme disrupts the membrane of Salmonella enterica. Molecular Immunology, 68(2), pp.421-433. https://doi.org/10.1016/j.molimm. 2015.10.001

Kumari, J. and Sahoo, P.K., 2006. Dietary $\beta-1,3$ glucan potentiates innate immunity and disease resistance of Asian catfish, Clarias batrachus (L.). Journal of Fish Diseases, 29(2), pp.95-101. https://doi.org/10.1111 /j.1365-2761.2006.00691.x

Kusumaningrum, H.D., Nasution, S., Kusumaningtyas, E. and Faridah, D.N., 2018. Lysozyme from Chicken Egg White as an Antibacterial Agent. Wartazoa, 28(4), pp.175-188. https://dx.doi.org/10.14334/warta zoa.v2814.1882

Lagler, K.F., Bardach, J.E., Miller, R.R. and Passino, D.R.M., 1977. Ichthyology, Translated from New York by John Willey and Sons, Inc, p.506.

Listyanto, N. and Andriyanto, S., 2009. Ikan gabus (Channa striata) manfaat pengembangan dan alternatif teknik budidayanya. Media Akuakultur, 4(1), pp.18-25. http://dx.doi.org/10.15578/ma.4.1 .2009.18-25

Manoppo, H., Tumbol, R.A. and Manurung, U.N., 2015. Incorporation of baker's yeast cells as immunostimulant in feed enhance resistance of nile tilapia to Aeromonas hydrophila. International Journal of PharmTech Research, 8(5), pp.797-802.
Misra, C.K., Das, B.K., Mukherjee, S.C. and Pattnaik, P., 2006. Effect of long term administration of dietary $\beta$ glucan on immunity, growth and survival of Labeo rohita fingerlings. Aquaculture, 255(1-4), pp.82-94. https://doi.org/10.1016/j.aquacult ure.2005.12.009

Moyle, P.B. and Cech, J.J., 2004. Fishes: an introduction to ichthyology (No. 597 MOY).

Mustafa, A., Widodo, M.A. and Kristianto, Y., 2012. Albumin and zinc content of snakehead fish (Channa striata) extract and its role in health. IEESE International Journal of Science and Technology, 1(2), pp.1-8. http://ww w.ieese.org/archieves/vol1n2.1.pdf

Olga, O., 2012. Patogenisitas Bakteri Aeromonas Hydrophila Asb01 Pada Ikan Gabus (Ophicephalus Striatus). Sains Akuatik: Jurnal Ilmiah IlmuIlmu Perairan, 14(1), pp.33-39. http://jurnalnasional.ump.ac.id/ind ex.php/AKUATIK/article/view/377

Ortuño, J., Cuesta, A., Rodŕnguez, A., Esteban, M.A. and Meseguer, J., 2002. Oral administration of yeast, Saccharomyces cerevisiae, enhances the cellular innate immune response of gilthead seabream (Sparus aurata L.). Veterinary immunology and immunopathology, 85(1-2), pp.4150. https://doi.org/10.1016/S0165 -2427(01)00406-8

Pal, D., Joardar, S.N. and Roy, B., 2007. Immunostimulatory effects of a yeast (Saccharomyces cerevisiae) cell wall feed supplement on rohu (Labeo rohita), an Indian major carp. The Israeli Journal of Aquaculture - Bamidgeh, 59(3), pp.175-181. http://hdl.handle.net/ 10524/19223

Paulsen, S.M., Lunde, H., Engstad, R.E. and Robertsen, B., 2003. In vivo effects of $\beta$-glucan and LPS on regulation of lysozyme activity and mRNA expression in Atlantic salmon (Salmo salar L.). Fish \& Shellfish Immunology, 14(1), pp.39-54. https: //doi.org/10.1006/fsim.2002.0416 
Pilarski, F., de Oliveira, C.A.F., de Souza, F.P.B.D. and Zanuzzo, F.S., 2017. Different $\beta$-glucans improve the growth performance and bacterial resistance in Nile tilapia. Fish \& shellfish immunology, 70, pp.25-29. https://doi.org/10.1016/j.fsi.2017. 06.059

Purwijantiningsih, E., Dewanti-Hariyadi, R. Nurwitri, C.C. and Istiana, 2005. Penghambatan Produksi Aflatoksin dari Aspergillus flavus oleh Kapang dan Khamir yang Diisolasi dari Ragi Tempe. Biota: Jurnal Ilmiah IlmuIlmu Hayati, 10(3), pp.146-153. https://doi.org/10.24002/biota.v1 $0 \mathrm{i} 3.2874$

Ray, S.D., Roy, D., Pal, S. and Homechaudhuri, S., 2016. Effects of beta glucan as immunostimulant on Labeo rohita challenged with a bacterial pathogen Aeromonas hydrophila. International Journal of Innovative Studies in Aquatic Biology and Fisheries, 2(5), pp.10-19. https:/ /dx.doi.org/10.20431/2454-7670.0 205003

Sajeevan, T.P., Philip, R. and Singh, I.B., 2009. Dose/frequency: a critical factor in the administration of glucan as immunostimulant to Indian white shrimp Fenneropenaeus indicus. Aquaculture, 287(3-4), pp.248-252. https://doi.org/10.1016/j.aquacult ure.2008.10.045

Sakai, M., 1999. Current research status of fish immunostimulants. Aquaculture, 172(1-2), pp.63-92. https://doi.org/10.1016/S0044-84 86(98)00436-0

Sirimanapong, W., Thompson, K.D., Ooi, E.L., Bekaert, M., Collet, B., Taggart, J.B., Bron, J.E., Green, D.M., Shinn, A.P., Adams, A. and Leaver, M.J., 2015. The effect of feeding $\beta$-glucan to Pangasianodon hypophthalmus on immune gene expression and resistance to Edwardsierla ictaluri. Fish \& Shellfish Immunology, 47(1), pp.595-605. https://doi.org/10.101 6/j.fsi.2015.09.042
Stier, H., Ebbeskotte, V. and Gruenwald, J., 2014. Immune-modulatory effects of dietary Yeast Beta-1, 3/1, 6-D-glucan. Nutrition journal, 13(1), pp.1-9. https://doi.org/10.1186/14 75-2891-13-38

Uribe, C., Folch, H., Enriquez, R. and Moran, G., 2011. Innate and adaptive immunity in teleost fish: a review. Veterinarni Medicina, 56(10), pp.486-503. https://doi.or $\mathrm{g} / 10.17221 / 3294-V E T M E D$

Vechklang, K., Boonanuntanasarn, S., Ponchunchoovong, S., Pirarat, N. and Wanapu, C., 2011. The potential for rice wine residual as an alternative protein source in a practical diet for Nile tilapia (Oreochromis niloticus) at the juvenile stage. Aquaculture Nutrition, 17(6), pp.685-694. https: //doi.org/10.1111/j.1365-2095.20 11.00870.x

Vetvicka, V. and Vetvickova, J., 2016. comparison of immunological effects of commercially available $\beta$ glucans: Part III. Int Clin Pathol $J$, 2(4), p.00046. http://dx.doi.org/10 .15406/icpjl.2016.02.00046

Wahyu, 2015. Respon fisiologis juvenil ikan gabus Channa striata pada transposrtasi sistem tertutup [Tesis]. Bogor (ID): Institut Pertanian Bogor.

Wedemeyer, G.A. and Yasutake, W.T., 1977. Clinical methods for the assessment of the effects of environmental stress on fish health (Vol. 89). Department of the Interior, Fish and Wildlife Service, pp.1-17.

Whittington, R., Lim, C. and Klesius, P.H., 2005. Effect of dietary $\beta$-glucan levels on the growth response and efficacy of Streptococcus iniae vaccine in Nile tilapia, Oreochromis niloticus. Aquaculture, 248(1-4), pp.217-225.

https://doi.org/10.1016/j.aquacult ure.2005.04.013 